\title{
Antibodies to hepatitis B virus surface antigen and interleukin 12 and interleukin 18 gene polymorphisms in hemodialysis patients
}

\author{
Alicja E Grzegorzewska1*, Piotr M Wobszal', Adrianna Mostowska² and Paweł P Jagodziński
}

\begin{abstract}
Background: The interleukin (IL)18 rs360719 CC genotype is associated with the development of antibodies to hepatitis B virus surface antigen (anti-HBs) in hemodialysis (HD) patients. IL18 shares biological properties with IL12 in promoting the T-hepler 1 (Th1) system. We studied whether polymorphisms in the IL12A $3^{\prime}$ untranslated region (UTR) and IL $12 B$ 3'UTR may contribute to anti-HBs development (titre $\geq 10 \mathrm{IU} / \mathrm{L}$ ) in HD patients either individually or jointly with the IL18 polymorphism.

Methods: In 518 HD patients and 240 controls the IL12A rs568408 3'UTR G > A polymorphism was genotyped by high-resolution melting curve analysis. Polymerase chain reaction restriction fragment length polymorphism was used to detect the IL12B rs3212227 3'UTR A >C and IL18 -1297 T > C rs360719 polymorphisms. The associations between the $I L 12 A, I L 12 B$ and $I L 18$ genotypes and the risk of impaired anti-HBs development were estimated by computing the odds ratios and their $95 \%$ confidence intervals using logistic regression analysis.

Results: In the logistic regression analysis, the higher frequency of rs360719 CC individually (2.9\% in 207 patients without anti-HBs development vs $8.0 \%$ in 311 patients with anti-HBs development, $p=0.009$ ) and of rs360719 CC combined with rs568408 GG ( $p=0.048)$, rs568408 GA ( $p=0.035)$, rs568408 GG/AA ( $p=0.034)$ or rs3212227 AA ( $p=0.046$ ) was associated with an increased chance for the development of anti-HBs in HD patients. Patients bearing both rs568408 AA and rs360719 TT had a 10.9-fold or 8.9-fold lower chance, respectively, to develop anti-HBs compared with those carrying any other genotype $(p=0.005)$ or those who had both wild-type rs568408 GG and rs360719 TT ( $p=0.011)$. Carriers of both rs3212227 CC and rs360719 TC had a 4.6-fold lower chance for anti-HBs development than carriers of any other genotype $(p=0.042)$.
\end{abstract}

Conclusion: Development of anti-HBs in HD patients is associated with gene polymorphisms of interleukins involved in the Th1 system.

Keywords: Antibodies to surface antigen of hepatitis B virus, Gene polymorphisms, Hemodialysis, Interleukin 12, Interleukin 18

\section{Background}

Chronic kidney disease patients on intermittent hemodialysis (HD) have been known to exhibit impaired immune system function with regards to the formation of antibodies against hepatitis B virus surface antigen (anti-HBs). Cytokines, among them interleukin (IL) 12 and IL18, play a key role in the regulation of hepatitis B

\footnotetext{
* Correspondence: alicja_grzegorzewska@yahoo.com

${ }^{1}$ Chair and Department of Nephrology, Transplantology and Internal Diseases Poznań University of Medical Sciences, 49 Przybyszewskiego Blvd, 60-355

Poznań, Poland

Full list of author information is available at the end of the article
}

virus (HBV) clearance and the immune response to HBV antigens during spontaneous natural infection [1-4] or planned vaccination [5-9].

IL-12 is a heterodimeric cytokine formed by a 35,000 dalton (Da) light chain (known as p35) and a 40,000 Da heavy chain (known as p40). The subunits p35 and p40 of IL12 are encoded by IL12A and IL12B, respectively, which are located on separate chromosomes (3p12-q13.2 and $5 \mathrm{q} 31-33)$. IL-18 is an $18,300 \mathrm{Da}$ cytokine. The human $I L-18$ gene is located on chromosome 11q22.2_q22.3. IL-12 shares biological properties with

\section{Biomed Central}


IL-18, known as an interferon (IFN) -gamma inducing factor [10-13]. In mice, IL-12 p40 and IL-18 acted in concert in a poxvirus infection [14]. In other studies using IL12 p40-/- or IL18-/ - mice, only IL-12 p40 or IL-18 was important for defense against human viruses adapted to the mouse $[15,16]$. In HD patients, the IL18 $-1297 C C$ rs360719 genotype, attributed to increased IL18 secretion [17], was recently connected with the development of anti-HBs [18]. It is not known whether the IL12 genotype is concomitantly associated with the IL18 genotype in the development of anti-HBs.

The aim of our study was to determine whether polymorphisms in $I L 12 A$ and $I L 12 B$ may individually or jointly with the IL18 polymorphism contribute to antiHBs development in HD patients. We have demonstrated that rs360719 CC individually and rs360719 CC combined with rs568408 GG, rs568408 GA, rs568408 GG/AA or rs3212227 AA are associated with an increased chance of developing anti-HBs in HD patients, whereas combined rs568408 AA and rs360719 TT or combined rs3212227 CC and rs360719 TC are associated with a lower chance of anti-HBs development. In HD the patients development of anti-HBs has been shown to be associated with gene polymorphisms of IL involved in the T-cell helper 1 (Th1) system.

\section{Methods}

\section{Patients and controls}

Studies were carried out in HD patients treated in 20 dialysis centers of the Wielkopolska region of Poland between February 11, 2009 and August 01, 2011. All patients with negative HBV seromarkers were vaccinated against HBV according to the standard rules for HD patients (4 vaccine doses of $40 \mu \mathrm{g}$ each were given at 0 1-2-6 months) [19]; an anti-HBs titre was checked after 4-8 weeks from the last vaccine dose. An anti-HBs titre $>10 \mathrm{IU} / \mathrm{L}$ is assumed to be protective in vaccinated patients [20]. When an anti-HBs titre remained below $10 \mathrm{IU} / \mathrm{L}$, vaccination against $\mathrm{HBV}$ was repeated. Due to fluctuations of anti-HBs in HD patients, blood testing for anti-HBs was repeated on a mandatory basis every 6 months to determine if vaccine booster doses were required.

Patients enrolled to the study had to fulfill the following criteria:

1. treatment with intermittent HD due to end-stage renal disease,

2. no signs and symptoms of acute infection with blood-borne viruses,

3. known anti-HBs titre (all available results of each patient were analyzed),

4. in patients without serological signs of HBV transmission, having an anti-HBs titre below $10 \mathrm{IU} /$
L, two full vaccination series against HBV (4 doses of $40 \mu$ g each given at $0-1-2-6$ months) had to be given or equivalent vaccine dosage had to be applied and the patients` anti-HBs titre had to be determined 4-8 weeks from the last vaccine dose,

5. from patients who disclosed a genetic relationship only one person could participate in the study,

6. written consent to participate in the study.

A response to HBsAg after vaccination or natural HBV transmission was considered to be positive when an anti-HBs titre exceeded $10 \mathrm{IU} / \mathrm{L}$.

The inclusion criteria were fulfilled by $518 \mathrm{HD}$ patients. These patients were divided into two groups dependent on anti-HBs development. Responders developed anti-HBs, whereas non-responders did not develop anti-HBs. Responders were the reference group for nonresponders.

Group I (HBsAg non-responders, $\mathrm{n}=207$ ) included HD patients who did not develop an anti-HBs titre $>10 \mathrm{IU} / \mathrm{L}$ in response to HBsAg from the HBV vaccine [patients with negative total antibodies to HBV core antigen (anti-HBc), $n=177$ ] or in response to $\mathrm{HBsAg}$ transmitted during natural HBV infection (patients with total anti-HBc positive, $n=30$ ). The available medical documents for these patients did not reveal any anti$\mathrm{HBs}>10 \mathrm{IU} / \mathrm{L}$.

Group II (HBsAg responders, $\mathrm{n}=311$ ) consisted of HD patients who developed an anti-HBs titre $>10 \mathrm{IU} /$ $\mathrm{L}$ as a result of vaccination (patients with total anti$\mathrm{HBC}$ negative, $\mathrm{n}=213$ ) or as a result of HBV transmission (patients with total anti-HBc positive, $\mathrm{n}=98$ ). In some patients with a long course of renal disease, a history of vaccination effectiveness revealed periods with or without anti-HBs $>10 \mathrm{IU} / \mathrm{L}$. If a patient had anti-HBs $>10 \mathrm{IU} / \mathrm{L}$ in the past but lost it during the course of renal disease, she/he was considered as constitutionally able to respond for $\mathrm{HBsAg}$ and was included into group II.

Registered blood donors from the Wielkopolska region of Poland $(\mathrm{n}=240)$, qualified for blood donation according to the criteria of Polish Ministry of Health [21], served as controls for HD patients. The control persons had serum alanine aminotransferase activity not higher than 2 times the upper normal limit of the applied laboratory method. All controls showed negative blood testing for HBsAg and HBV DNA as well as for seromarkers of infection with the hepatitis $C$ virus. Unfortunately, the vaccination rate against $\mathrm{HBV}$ and an antiHBs titre were not known in these healthy individuals.

Genotype analysis for rs568408 3'UTR G>A in IL12A, rs3212227 3'UTR A > C in IL12B and $-1297 \mathrm{C} / \mathrm{T}$ rs360719 in IL18 was done in all HD patients and controls. 


\section{Laboratory methods}

HBsAg and anti-HBc were determined by Microparticle Enzyme Immunoassay (MEIA) technology (AxSYM, Abbott Laboratories, Abbott Park, USA). MEIA technology (ABBOTT, Wiesbaden, Germany) was also used for detection of anti-HBs and antibodies to hepatitis $\mathrm{C}$ virus (anti-HCV). HBV DNA was determined using a qualitative test COBAS AMPLICOR HBV MONITOR; $\mathrm{HCV}$ RNA was tested using COBAS AMPLICOR Hepatitis C Virus Test, version 2.0 (both Roche Diagnostics Ltd., Rotkreutz, Switzerland). Serum activities of liver enzymes were determined by routine laboratory methods.

\section{IL12A, IL12B and IL18 genotyping}

DNA was isolated from peripheral leukocytes using a standard salting out procedure.

The IL12A 3'UTR G>A (rs568408) DNA fragments were amplified using primers 5' ATGAGGAAACTTTGA TAGGATG 3' and 5'TTCCCTTCTTAGCAATTCATTC 3'. This polymorphism was then genotyped by highresolution melting curve analysis (HRM) using the Light Cycler 480 system (Roche Diagnostics, Mannheim, Germany).

Identification of the IL12B 3'UTR A > C (rs3212227) and $I L-18-1297 \mathrm{~T}>\mathrm{C}$ (rs360719) polymorphic variants was carried out by polymerase chain reaction-restriction fragment length polymorphism (PCR-RFLP). PCR for IL12B 3'UTR A > C (rs3212227) was conducted using the primer pair 5' TTAAAGACACAACGGAATAGAC 3'and 5' TGCTTTATCAACACCATCTCC 3'. The PCRamplified fragments of $I L 12 B$ that were 557 bp in length were isolated and digested with the endonuclease TaqI (T/CGA) (New England Biolabs, Ipswich, USA). The ILI2B 3'UTR A allele remained uncut whereas the IL12B 3'UTR C allele was cleaved into $454 \mathrm{bp}$ and 103 bp fragments. PCR for $I L-18-1297 \mathrm{~T}>\mathrm{C}$ (rs360719) was conducted using the primer pair 5' CAACAGT GATTACAAAGGAAGT 3' and 5' TAAATGGGTAG GAATAAGTGAGA 3'. The PCR-amplified fragments of IL-18 474 bp in length were digested with endonuclease NlaIII (CATG/) (New England Biolabs, Ipswich, USA). The $I L-18 \mathrm{C}$ allele remained uncut, whereas the $I L-18 \mathrm{~T}$ allele was cleaved into $295 \mathrm{bp}$ and 179 bp fragments. DNA digestion products for the IL12B 3'UTR A $>C$ and IL-18 -1297 $\mathrm{T}>\mathrm{C}$ polymorphisms were separated by electrophoresis on $2 \%$ agarose gel and visualized by ethidium bromide staining. The PCR-RFLP analysis was repeated for all patient and control samples.

For quality control of the tested polymorphisms, approximately $10 \%$ of the randomly chosen samples were re-genotyped using commercial sequencing.

\section{Statistical methods}

Differences in the distributions of demographic characteristics and selected variables between the examined groups were analyzed. The normality of distribution of variables was checked by the Shapiro-Wilk test. Descriptive statistics are presented as percentage for categorical variables, as mean with one standard deviation for normally distributed continuous variables or as median with range for not normally distributed continuous variables. The prevalence of variables was assessed by the chi square $\left(X^{2}\right)$ test or Yates ' test, as appropriate. Results were compared using Student's $t$-test for non-paired data if distribution of variables was normal or the MannWhitney $U$-test for other than normal distributions.

Hardy-Weinberg equilibrium was tested by a goodness-of-fit $\mathrm{m} 2$ test to compare the observed genotype frequencies to the expected ones. Power analysis was conducted employing the Fisher exact test, which was available at an on-line internet service, http://biostat.mc.vanderbilt.edu/twiki/bin/view/ Main/ PowerSampleSize.

The associations between the IL12A,IL12B and IL18 genotypes and risk of impaired anti-HBs development were estimated by computing the odds ratios (OR) and their $95 \%$ confidence intervals $(95 \% \mathrm{CI})$ using logistic regression analysis. To address the possibility of a genegene interaction effect between analyzed polymorphisms, a Multifactor Dimensionality Reduction (MDR) approach (MDR version 2.0 beta 5) was used [22].

Values of $P<0.05$ were judged to be significant.

\section{Ethical issues}

This study was approved by the Institutional Review Board of Poznań University of Medical Sciences, Poland.

\section{Results}

The selected demographic, clinical and laboratory data of groups I (non-responders) and II (responders) are shown in Table 1. All patients were Caucasian. The patients in group I were significantly older and had shorter duration of renal replacement therapy (RRT). Among the 4 main causes of end-stage renal disease in groups I and II diabetic nephropathy was the most frequent with the least frequent being chronic glomerulonephritis in group I and chronic tubulointerstitial nephritis in group II. Significant differences in HBV seromarkers between groups resulted from categorization of patients to groups I or II.

There was no significant deviation from HardyWeinberg equilibrium in the genotype frequencies in HD patients of groups I and II (Table 2), and in controls (Table 3).

The logistic regression analysis (Table 2), performed in HD patients with a titre of anti-HBs $\leq 10 \mathrm{UI} / \mathrm{L}$ (Group I) or $>10 \mathrm{UI} / \mathrm{L}$ (Group II), revealed that a lower frequency of the rs360719 CC genotype was individually associated with a significantly increased risk of immune non-responsiveness 
Table 1 Data of all patients and of subjects grouped by a titre of antibodies to surface antigen of hepatitis B virus $\leq$ $10 \mathrm{UI} / \mathrm{L}$ (Group I) and > $10 \mathrm{UI} / \mathrm{L}$ (Group II)

\begin{tabular}{|c|c|c|c|c|}
\hline Parameter & All patients $\mathrm{N}=518$ & Group I n= 207 & Group II $n=311$ & $\begin{array}{l}P \text { value for analysis } \\
\text { between groups I and II }\end{array}$ \\
\hline Men, $\mathrm{n}$ (\% of all) & $290(56.0)$ & $110(53.1)$ & $180(57.9)$ & 0.320 \\
\hline Age, years & $62.5 \pm 15.5$ & $64.8 \pm 14.9$ & $60.9 \pm 15.8$ & 0.004 \\
\hline RRT duration, years & $1.82(0.002-26.1)$ & $1.24(0.04-23.8)$ & $2.71(0.002-26.1)$ & 0.001 \\
\hline Diabetic nephropathy, n (\% of all) & $141(27.2)$ & $72(34.8)$ & $69(22.2)$ & 0.002 \\
\hline Chronic glomerulonephritis, n (\% of all) & $86(16.6)$ & $22(10.6)$ & $64(20.6)$ & 0.003 \\
\hline Hypertensive nephropathy, n (\% of all) & $84(16.2)$ & $34(16.4)$ & $50(16.1)$ & 1.000 \\
\hline Chronic tubulointerstitial nephritis, n (\% of all) & $60(11.6)$ & $24(11.6)$ & $36(11.6)$ & 1.000 \\
\hline History of acute hepatitis, $\mathrm{n}$ (\% of all) & $23(4.4)$ & $6(2.9)$ & $17(5.5)$ & 0.195 \\
\hline Positive HBsAg, n (\% of all) & $16(3.1)$ & $13(6.3)$ & $3(1.0)$ & 0.001 \\
\hline Positive HBV DNA, n (\% of all HBsAg positive) & $16(100.0)^{*}$ & $13(100.0)$ & $3(100.0)$ & 1.000 \\
\hline Positive anti-HBC, n (\% of all) & $128(24.7)$ & $30(14.5)$ & $98(31.5)$ & $<0.0001$ \\
\hline Isolated positive anti-HBC, $\mathrm{n}$ (\% of all anti-HBC positive) & $17(13.3)$ & $17(56.7)$ & $0(0.0)$ & $<0.0001$ \\
\hline $\begin{array}{l}\text { Full vaccination series against HBV with developed } \\
\text { anti-HBs titre }>10 \mathrm{IU} / \mathrm{L} \text { in anti-HBC negative patients, } \mathrm{n} \\
\text { (\% of all anti-HBC negative patients) }\end{array}$ & $213(54.6)$ & $0(0.0)$ & $213(100.0)$ & $<0.0001$ \\
\hline Positive anti-HCV, $\mathrm{n}$ (\% of all) & $55(10.6)$ & $20(9.7)$ & $35(11.3)$ & 0.663 \\
\hline Positive HCV RNA ( $n, \%$ of all examined anti-HCV positive) & $32(58.2)$ & $9(45.0)$ & $23(65.7)$ & 0.163 \\
\hline$\overline{A L T}(U / L)$ & $13(0.6-209)$ & $14(0.6-126)$ & $13(2-209)$ & 0.392 \\
\hline AST (U/L) & $14(4-177)$ & $14(5-97)$ & $14.5(4-177)$ & 0.570 \\
\hline$\overline{\mathrm{GGT}}(\mathrm{U} / \mathrm{L})$ & $27(0-498)$ & $28(5-308)$ & $26(0-498)$ & 0.757 \\
\hline
\end{tabular}

* HBeAg was checked in two HBV DNA positive patients, being on the transplant waiting list, and the results were negative. HBV viral load was determined in three patients and varied from 4,210 to $1.19 \mathrm{E}+09$ copies $/ \mathrm{mL}$.

Data are expressed as mean \pm standard deviation or median and range.

Significant results are indicated using bold font.

Abbreviations: $A L T$ - alanine aminotransferase, anti-HBC - antibodies to core antigen of hepatitis B virus, anti-HBs - antibodies to surface antigen of hepatitis B virus, anti-HCV - antibodies to hepatitis C virus, $A S T$ - aspartate aminotransferase, GGT - gamma-glutamyltranspeptidase, $H B e A g$ - antigen e of hepatitis B virus, $H B s A g$ - surface antigen of hepatitis B virus, HBV - hepatitis B virus, HBV DNA - deoxyribonucleic acid of hepatitis B virus, HCV RNA - ribonucleic acid of hepatitis $C$ virus, $R R T$ - renal replacement therapy.

to HBsAg. The rs360719 CC variant was associated with a 3.13-fold increased chance to develop anti-HBs in HD patients $(P=0.009)$. The logistic regression analysis (Table 3), performed in HD patients with a titre of anti-HBs $\leq 10 \mathrm{UI} / \mathrm{L}$ (Group I) and controls, also revealed that a lower frequency of the rs360719 CC variant was associated with a significantly $(P=0.006)$ increased risk of immune nonresponsiveness to HBsAg compared with the rs360719 TT variant.

Selected combined or dichotomized effects of the IL12A rs568408 3'UTR G>A, IL12B rs3212227 3'UTR A > C and $-1297 \mathrm{~T}>\mathrm{C}$ (rs360719) IL-18 variants on the development of anti-HBs in HD patients are shown in Tables 4 and 5, respectively. A higher frequency of rs360719 CC combined with rs568408 GG, rs568408 GA or rs568408 GG/AA was associated in HD patients with a significantly higher chance to develop anti-HBs $(P=0.048, P=0.035$ and $P=0.034$, respectively) compared to HD patients having both wild-type genotypes (rs568408 GG and rs360719 TT). A higher frequency of $360719 \mathrm{CC}$ combined with rs3212227 AA was also associated with anti-HBs development in HD patients $(P=0.046)$ compared to HD patients bearing both rs3212227 AA and rs360719 TT. Combined rs568408 AA and rs360719 TT were associated with an 8.94-fold increased risk of non-responsiveness (antiHBs $<10 \mathrm{IU} / \mathrm{L}) \quad(P=0.011)$ compared to the combined effects of rs568408 GG and rs360719 TT (Table 4) and with a 10.85-fold elevated risk of non-responsiveness $(P=0.005)$ compared to all other genotypes (Table 5). Combined rs3212227 CC and rs360719 TC were associated with a 4.61-fold increased risk of nonresponsiveness $(P=0.042)$ compared to all other genotypes (Table 5). There were no significant effects of having the combined rs568408 and rs3212227 variants.

MDR approach revealed a borderline gene-gene interaction effect between the analyzed polymorphic variants of IL12A, IL12B and IL18 in HD patients of both groups (testing balance accuracy $=0.556, \mathrm{p}=0.094$ ).

\section{Discussion}

Vaccination against HBV resulting in the formation of an anti-HBs titre conferring protection (over $10 \mathrm{IU} / \mathrm{L}$ [20]) was reported in only $54 \%-86 \%$ of HD patients using a recombinant vaccine [23-26]. HD patients that 
Table 2 IL12 and IL18 polymorphisms in hemodialysis patients with a titre of antibodies to surface antigen of hepatitis B virus $\leq 10 \mathrm{UI} / \mathrm{L}$ (Group I) and $>10 \mathrm{UI} / \mathrm{L}$ (Group II)

\begin{tabular}{|c|c|c|c|c|c|}
\hline Variable & $\begin{array}{l}\text { Group I }(n=207) \\
n(\%)\end{array}$ & $\begin{array}{l}\text { Group II }(n=311) \\
n(\%)\end{array}$ & OR (95 \% Cl) & $P$ value & $\begin{array}{l}\text { Genotype frequencies ( } n, \%) \\
\text { expected by Hardy-Weinberg } \\
\text { equilibrium, Group I; Group II }\end{array}$ \\
\hline \multicolumn{6}{|c|}{ IL12A rs568408 } \\
\hline GG & $157(75.8)$ & $220(70.7)$ & 1.00 & & 152 (73.5); 222 (71.5) \\
\hline $\mathrm{GA}$ & $41(19.8)$ & $86(27.7)$ & $0.67(0.44-1.02)$ & 0.059 & $51(24.4) ; 81$ (26.1) \\
\hline $\mathrm{AA}$ & $9(4.4)$ & $5(1.6)$ & $2.52(0.83-7.70)$ & 0.094 & $4(2.0) ; 7(2.4)$ \\
\hline GA/AA & $50(24.2)$ & $91(29.3)$ & $0.77(0.51-1.15)$ & 0.199 & $P=0.213 ; P=0.783$ \\
\hline \multicolumn{6}{|c|}{ IL $12 B$ rs3212227 } \\
\hline $\mathrm{AA}$ & $129(62.3)$ & $193(62.1)$ & 1.00 & & $130(62.8 ;) 198$ (63.6) \\
\hline$A C$ & 70 (33.8) & $110(35.4)$ & $0.95(0.65-1.38)$ & 0.796 & $68(32.9) ; 100$ (32.3) \\
\hline $\mathrm{CC}$ & $8(3.9)$ & $8(2.6)$ & $1.50(0.55-4.10)$ & 0.433 & $9(4.3) ; 13(1.4)$ \\
\hline $\mathrm{AC/CC}$ & $78(37.7)$ & $118(37.4)$ & $0.99(0.69-1.42)$ & 0.952 & $P=0.783 ; P=0.421$ \\
\hline \multicolumn{6}{|c|}{ IL18 rs360719 } \\
\hline$\pi$ & $118(57.0)$ & $160(51.4)$ & 1.00 & & $123(59.4) ; 160$ (51.4) \\
\hline $\mathrm{TC}$ & $83(40.1)$ & $126(40.5)$ & $0.89(0.62-1.29)$ & 0.544 & $73(35.4) ; 126(40.5)$ \\
\hline $\mathrm{CC}$ & $6(2.9)$ & $25(8.0)$ & $0.32(0.13-0.82)$ & 0.009 & $11(5.4) ; 25(8.0)$ \\
\hline $\mathrm{TC} / \mathrm{CC}$ & $89(43.0)$ & $151(48.6)$ & $0.80(0.56-1.14)$ & 0.214 & $P=0.330 ; P=1.000$ \\
\hline
\end{tabular}

A significant result (a sample power $72.7 \%$ ) is indicated using bold font.

do not respond to vaccination are susceptible to HBV infection. Natural HBV transmission, if it does not lead to anti-HBs development, results in:

1. HBsAg carrier status, which is usually associated with persistent HBV replication (in this study HBV DNA was detected in all HBsAg positive patients) and infectivity to other persons,

2. occurrence of isolated anti-HBc positivity (anti-HBc positive persons are both $\mathrm{HBsAg}$ and anti-HBs negative), which is associated in approximately $8 \%$ of cases with HBV DNA detectable in the blood [27].

Moreover, an anti-HBs titre $>10 \mathrm{IU} / \mathrm{L}$ in $\mathrm{HD}$ patients is not always protective against HBV infection and seroconversions to anti-HBc positivity, also without clinical signs of disease, may occur [28].

Prevalence of HBsAg carrier status or isolated anti$\mathrm{HBc}$ positivity in HD patients varies between individual HD facilities. As shown in this study, HBsAg carriers amounted for $3.1 \%$ of all HD patients and isolated anti$\mathrm{HBc}$ positivity occurred in $13.3 \%$ of the anti-HBc positive HD patients. As such frequencies are in the medium range [26,29-31], these results indicate thousands of affected HD people worldwide.

The reasons of non-responsiveness to $\mathrm{HBsAg}$ are not fully understood. It has been shown that effective seroconversion after vaccination of HD patients depends on age, body mass, serum albumin concentration, type of dialyzer, duration of RRT, and underlying kidney disease [18,32-36]. Such risk factors of non-responsiveness as older age, shorter RRT duration and diabetic nephropathy were also present in the examined non-responders compared to responders.

Genetic aspects of responsiveness to $\mathrm{HBsAg}$ were also taken into account, linking responsiveness with the human leukocyte antigen system $[37,38]$. More recently, IL genotypes (IL10, IL-18) were associated with anti-HBs development in response to $\mathrm{HBsAg}$ in $\mathrm{HD}$ patients [18,39].

IL12 and IL18 share biological properties through their synergism in the promotion of IFN-gamma production [11-13,40,41]. IL12, generated by macrophages, monocytes, dendritic cells, and B cells, is significantly elevated in HD patients [42-46], but despite this increase a constitutive IFN-gamma release by peripheral blood mononuclear cells (PBMCs) of HD patients may be undetectable [45]. Plasma levels of free IL18 are also increased in dialysis patients [47], but Th1 lymphocyte immunodeficiency was reported owing to the deficit of IFN-gamma [44,47]. Thereby, genes promoting expression of these IL may be helpful under specific clinical conditions. In experimental studies, mice immunized with an HBV DNA vaccine and the DNA fragments containing the p35 and p40 coding sequences of murine IL-12 demonstrated increased production of both immunoglobulin (Ig) $\mathrm{M}$ and IgG anti-HBs titers [5]. Mice vaccinated with a recombinant plasmid carrying the gene encoding HBsAg linked to a DNA segment encoding full-length murine IL18 revealed significant serum antiHBs IgG response after two intramuscular injections [8]. These effects may be related to the indirect influence of 
Table 3 IL12 and IL18 polymorphisms in hemodialysis patients with a titre of antibodies to surface antigen of hepatitis B virus $\leq 10 \mathrm{UI} / \mathrm{L}$ (Group II) and controls

\begin{tabular}{|c|c|c|c|c|c|}
\hline Variable & $\begin{array}{l}\text { Group I }(n=207) \\
n(\%)\end{array}$ & $\begin{array}{l}\text { Controls }(n=240) \\
N(\%)\end{array}$ & OR $(95 \% \mathrm{Cl})$ & $P$ value & $\begin{array}{l}\text { Genotype frequencies ( } n, \%) \\
\text { expected by Hardy-Weinberg } \\
\text { equilibrium Controls }\end{array}$ \\
\hline \multicolumn{6}{|c|}{ IL12A rs568408 } \\
\hline$\overline{G G}$ & $157(75.8)$ & $171(71.3)$ & 1.00 & & $171(71.3)$ \\
\hline $\mathrm{GA}$ & $41(19.8)$ & $63(26.3)$ & $0.71(0.45-1.11)$ & 0.131 & $63(26.3)$ \\
\hline$\overline{\mathrm{AA}}$ & $9(4.4)$ & $6(2.5)$ & $1.63(0.57-4.71)$ & 0.357 & $6(2.5)$ \\
\hline GA/AA & $50(24.2)$ & $69(28.8)$ & $0.79(0.52-1.21)$ & 0.272 & $P=1.000$ \\
\hline \multicolumn{6}{|c|}{ IL12B rs3212227 } \\
\hline $\mathrm{AA}$ & $129(62.3)$ & $151(62.9)$ & 1.00 & & $150(62.3)$ \\
\hline$\overline{A C}$ & 70 (33.8) & $77(32.1)$ & $1.06(0.71-1.59)$ & 0.761 & 80 (33.2) \\
\hline$\overline{C C}$ & $8(3.9)$ & $12(5.0)$ & $0.78(0.31-1.97)$ & 0.597 & $11(4.4)$ \\
\hline$\overline{A C / C C}$ & $78(37.7)$ & 89 (37.1) & $1.03(0.70-1.51)$ & 0.896 & $P=0.950$ \\
\hline \multicolumn{6}{|c|}{ IL18 rs360719 } \\
\hline$\pi$ & $118(57.0)$ & $121(50.4)$ & 1.00 & & $120(50.2)$ \\
\hline$\overline{\mathrm{TC}}$ & $83(40.1)$ & $98(40.8)$ & $0.87(0.59-1.28)$ & 0.475 & 99 (41.3) \\
\hline$\overline{C C}$ & $6(2.9)$ & $21(8.8)$ & $0.29(0.11-0.75)$ & 0.006 & $20(8.5)$ \\
\hline$\overline{\mathrm{TC} / \mathrm{CC}}$ & $89(43.0)$ & $119(49.6)$ & $0.77(0.53-1.11)$ & 0.163 & $P=0.950$ \\
\hline
\end{tabular}

A significant result (a sample power $78.1 \%$ ) is indicated using bold font.

these cytokines on anti-HBs development, may be mediated through the observed increased INF-gamma production or both. In this study neither the IL12A rs568408 nor the $I L 12 B$ rs3212227 polymorphic variants were individually associated with anti-HBs development in the examined HD patients as was shown for IL18 rs360719 CC. However, patients bearing the IL18 rs360719 CC genotype had a greater chance to develop anti-HBs also when occurring concomitantly with the IL12A rs568408 GG, IL12A rs568408 GA or rs3212227 AA polymorphic variants, but the IL12A rs568408 AA and $I L 12 B$ rs3212227 CC variants occurring together with other than the CC variant of IL18 rs360719 were negatively associated with anti-HBs development.

Liu et al.. [48] using http://pupasuite.bioinfo.cipf.es/, http://exon.cshl.edu/ESE/ and http://genes.mit.edu/burgelab/rescueese found that rs568408 may disrupt exonic splicing enhancers. They hypothesized that IL12 mRNA may be unstable or that IL12 secretion may be lower due to disrupted exonic splicing, which was suggested as a functional characterization of IL12A rs568408. Decreased IL12 secretion results in lower INF-gamma levels [41]. Liu et al. [48] showed that the IL12A rs568408 AA and $I L 12 A$ rs568408 GA/AA genotypes were more frequent in patients suffering from hepatocellular carcinoma compared to controls. These patients were HBsAg positive in $73.5 \%$ of cases, thereby, near exclusively anti-HBs negative, whereas controls were HBsAg positive in $12.6 \%$ of cases. Although the antiHBs titre is not mentioned in the study by Liu et al. [48], their data directly indicate that A allele of IL12A is associated with a lack of anti-HBs development. In our study, HD patients with an anti-HBs titre $\leq 10 \mathrm{IU} / \mathrm{L}$ had a higher frequency of $I L 12 A$ rs568408 AA in association with IL18 rs360719 TT than did HD patients with antiHBs titre $>10$ IU/L. Studies by Sánchez et al. [17] indicate that inhibitory transcription factor OCT-1 binds to the $\mathrm{T}$ allele but not to the $\mathrm{C}$ allele at position -1297 (rs360719). The rs360719 $\mathrm{T}$ allele was identified as a possible major repressor site in the $I L-18$ promoter. This suppression would result in reduced IL-18 production.

Functional characterization of IL12B rs3212227 3'UTR $\mathrm{A} / \mathrm{C}$ is not clear. Morahan et al. [49] observed that the rs3212227AA genotype was associated with a significantly elevated expression of IL12 in Epstein-Barr virus transformed human cell lines. Similar results were reported using peripheral lymphocytes: the expression of the $1159 \mathrm{~A}$ allele was approximately $50 \%$ higher than that of the $1159 \mathrm{C}$ allele [50]. On the other hand, Seegers et al. [51] correlated a TaqI polymorphism $(\mathrm{C} / \mathrm{C})$ in $I L$ $12 B$ p 40 3'UTR with increased IL-12B p70 secretion by stimulated monocytes. Additionally, Yilmaz et al. [52] associated the $1188 \mathrm{~A} / \mathrm{C}$ polymorphism in the $3^{\prime} \mathrm{UTR}$ of the $I L-12 B$ gene with the expression of IL- $12 B$ mRNA and IL-12B secretion level from lipopolysaccharide (LPS) and purified protein derivative (PPD) stimulated PBMCs. Individuals $+16974 C C$ homozygous at the $I L 12 B$ 3'UTR had significantly higher IL-12 secretion levels from LPS and PPD stimulated PBMCs than AC heterozygotes or AA homozygotes [52]. Sánchez et al. [17] found a significant increase in the relative expression of IL-18 mRNA in individuals carrying the rs360719 C allele. As 
Table 4 The selected combined effects of IL12 and IL18 polymorphisms in hemodialysis patients with a titre of antibodies to surface antigen of hepatitis B virus $\leq 10 \mathrm{UI} / \mathrm{L}$ (Group I) and $>10 \mathrm{UI} / \mathrm{L}$ (Group II)

\begin{tabular}{|c|c|c|c|c|c|}
\hline Variable & $\begin{array}{l}\text { Group I } \\
(n=207) n(\%)\end{array}$ & $\begin{array}{l}\text { Group II } \\
(n=311) n(\%)\end{array}$ & OR $(95 \% \mathrm{Cl})$ & $P$ value & $\begin{array}{l}\text { Sample power (\%) for } \\
\text { significant differences }\end{array}$ \\
\hline \multicolumn{6}{|l|}{ Combined effects of rs568408 and rs360719 } \\
\hline rs568408 GG and rs360719 TT & $90(43.5)$ & $115(37.0)$ & 1.00 & & \\
\hline rs568408 GG and rs360719 TC & $62(30.0)$ & $88(28.3)$ & $0.90(0.59-1.38)$ & 0.629 & \\
\hline rs568408 GG and rs360719 CC & $5(2.4)$ & $17(5.5)$ & $0.38(0.13-1.06)$ & 0.048 & 45.7 \\
\hline rs568408 GG and rs360719 TC/CC & $67(32.4)$ & $105(33.8)$ & $0.81(0.54-1.23)$ & 0.331 & \\
\hline rs568408 GA and rs360719 TT & $21(10.1)$ & $44(14.1)$ & $0.61(0,34-1.10)$ & 0.095 & \\
\hline rs568408 GA and rs360719 TC & $19(9.2)$ & $34(10.9)$ & $0.71(0.38-1.34)$ & 0.287 & \\
\hline rs568408 GA and rs360719 CC & $1(0.48)$ & $8(2.6)$ & $0.16(0.02-1.32)$ & 0.035 & 45.3 \\
\hline rs568408 GA and rs360719 TC/CC & $20(9.7)$ & $42(13.5)$ & $0.61(0.33-1.11)$ & 0.099 & \\
\hline rs568408 GA/AA and rs360719 TT & $28(13.5)$ & $43(13.8)$ & $0.83(0.48-1.45)$ & 0.511 & \\
\hline rs568408 GA/AA and rs360719 TC & $21(10.1)$ & $38(12.2)$ & $0.71(0.39-1,29)$ & 0.252 & \\
\hline rs568408 GA/AA and rs360719 CC & $1(0.48)$ & $8(2.6)$ & $0.16(0.02-1.32)$ & 0.034 & 45.3 \\
\hline rs568408 GA/AA and rs360719 TC/CC & $22(10.6)$ & $48(15.4)$ & $0.59(0.33-1.04)$ & 0.064 & \\
\hline rs568408 AA and rs360719 TT & $7(3.4)$ & $1(0.32)$ & $8.94(1.07-74.94)$ & 0.011 & 65.5 \\
\hline rs568408 AA and rs360719 TC & $2(0.97)$ & $4(1.3)$ & $0.64(0.11-3.60)$ & 0.602 & \\
\hline rs568408 AA and rs360719 CC & $0(0)$ & $0(0)$ & - & - & \\
\hline \multicolumn{6}{|c|}{ Combined effects of rs3212227 and rs360719 } \\
\hline rs3212227 AA and rs360719 Tा & $76(36.7)$ & $102(32.8)$ & 1.00 & & \\
\hline rs3212227 AA and rs360719 TC & $48(23.2)$ & $73(23.5)$ & $0.88(0.55-1.41)$ & 0.602 & \\
\hline rs3212227 AA and rs360719 CC & $5(2.4)$ & $18(5.8)$ & $0.37(0.13-1.05)$ & 0.046 & 49.4 \\
\hline rs3212227 AA and rs360719 TC/CC & $53(25.6)$ & $91(29.3)$ & $0.78(0.50-1.23)$ & 0.283 & \\
\hline rs3212227 AC and rs360719 TT & $40(19.3)$ & $52(16.7)$ & $1.03(0.62-1.72)$ & 0.902 & \\
\hline rs3212227 AC and rs360719 TC & $29(14.0)$ & $51(16.4)$ & $0.76(0.44-1.32)$ & 0.328 & \\
\hline rs3212227 AC and rs360719 CC & $1(0.48)$ & $7(2.3)$ & $0.19(0.02-1.61)$ & 0.068 & \\
\hline rs3212227 AC and rs360719 TC/CC & $30(14.5)$ & $59(19.0)$ & $0.68(0.40-1.16)$ & 0.155 & \\
\hline rs3212227 AC/CC and rs360719 TT & $42(20.3)$ & $58(18.6)$ & $0.97(0.59-1.60)$ & 0.910 & \\
\hline rs3212227 AC/CC and rs360719 TC & $35(16.9)$ & $53(17.0)$ & $0.89(0.52-1.49)$ & 0.649 & \\
\hline rs3212227 AC/CC and rs360719 CC & $1(0.48)$ & $7(2.3)$ & $0.19(0.02-1.61)$ & 0.068 & \\
\hline rs3212227 AC/CC and rs360719 TC/CC & $36(17.4)$ & $60(19.3)$ & $0.80(0.48-1.34)$ & 0.403 & \\
\hline rs3212227 CC and rs360719 TT & $2(0.97)$ & $6(1.9)$ & $0.45(0.09-2.30)$ & 0.307 & \\
\hline rs3212227 CC and rs360719 TC & $6(2.9)$ & $2(0.64)$ & $4.03(0.78-20.72)$ & 0.069 & \\
\hline rs3212227 CC and rs360719 CC & $0(0)$ & $0(0)$ & - & - & \\
\hline rs3212227 CC and rs360719 TC/CC & $6(2.9)$ & $2(0.64)$ & $4.03(0.78-20.72)$ & 0.069 & \\
\hline
\end{tabular}

Significant results are indicated using bold font.

shown in this study, combined effects of $I L-18$ rs360719 CC and $I L 12 B$ rs 3212227 AA were positively associated with anti-HBs development. In this case, an elevated expression of IL18 could be accompanied by increased expression of IL12B. Thereby, our results confirm previous results indicating that $I L 12 B$ rs 3212227 AA is associated with elevated IL12 levels $[49,50]$.

It has been discussed that genetic investigations could help in the development of new and improved vaccines against HBV and may eventually reduce the proportion of vaccine failures [53]. It has been shown that the use of exogenous IL12 as an adjuvant to augment anti-HBs development in response to vaccines against $\mathrm{HBV}$ $[54,55]$ may help overcome at least some immunologic deficits of genetic origin. There are also experimental studies that take advantage of the recombinant plasmid carrying gene encoding the HBsAg linked to DNA segment encoding full-length murine IL18 [8]. We have suggested such a vaccine for non-responders bearing other IL18 polymorphic variants than -1297 CC rs360719 [18]. However, at present we are very careful in our conclusions, because associations that have been found between polymorphic variants of genes encoding cytokines may disturb the unique homeostasis between 
Table 5 Selected dichotomized effects of IL12A rs568408 and IL18 rs360719 in hemodialysis patients with a titre of antibodies to surface antigen of hepatitis B virus $\leq 10 \mathrm{UI} / \mathrm{L}$ (Group I) and > $10 \mathrm{UI} / \mathrm{L}$ (Group II)

\begin{tabular}{|c|c|c|c|c|c|}
\hline Variable & $\begin{array}{l}\text { Group I } \\
(n=207) \text { n (\%) }\end{array}$ & $\begin{array}{l}\text { Group II } \\
(n=311) n(\%)\end{array}$ & OR $(95 \% \mathrm{Cl})$ & $P$ value & $\begin{array}{l}\text { Sample power (\%) for } \\
\text { significant differences }\end{array}$ \\
\hline \multicolumn{6}{|c|}{ Dichotomized genotypes of rs568408 and rs360719 } \\
\hline All other genotypes & $202(97.6)$ & $294(94.5)$ & 1.00 & & \\
\hline rs568408 GG and rs360719 CC & $5(2.4)$ & $17(5.5)$ & $0.43(0.15-1.18)$ & 0.080 & \\
\hline All other genotypes & $185(89.4)$ & $263(84.6)$ & 1.00 & & \\
\hline rs568408 GA/AA and rs360719 TC/CC & $22(10.6)$ & $48(15.4)$ & $0.65(0.38-1.12)$ & 0.112 & \\
\hline All other genotypes & $206(99.5)$ & $303(97.4)$ & 1.00 & & \\
\hline rs568408 GA and rs360719 CC & $1(0.48)$ & $8(2.6)$ & $0.18(0.02-1.49)$ & 0.052 & \\
\hline rs568408 GA/AA and rs360719 CC & $1(0.48)$ & $8(2.6)$ & $0.18(0.02-1.49)$ & 0.052 & \\
\hline All other genotypes & $200(96.6)$ & $310(99.7)$ & 1.00 & & \\
\hline rs568408 AA and rs360719 TT & $7(3.4)$ & $1(0.32)$ & $10.85(1.32-89.30)$ & 0.005 & 75.2 \\
\hline All other genotypes & $202(97.6)$ & $293(94.2)$ & 1.00 & & \\
\hline rs3212227 AA and rs360719 CC & $5(2.4)$ & $18(5.8)$ & $0.40(0.15-1.10)$ & 0.058 & \\
\hline All other genotypes & $206(99.5)$ & $304(97.7)$ & 1.00 & & \\
\hline rs3212227 AC and rs360719 CC & $1(0.48)$ & $7(2.3)$ & $0.21(0.03-1.73)$ & 0.084 & \\
\hline All other genotypes & $206(99.5)$ & $304(97.7)$ & 1.00 & & \\
\hline rs3212227 AC/CC and rs360719 CC & $1(0.48)$ & $7(2.3)$ & $0.21(0.03-1.73)$ & 0.084 & \\
\hline All other genotypes & $201(97.1)$ & 309 (99.4) & 1.00 & & \\
\hline rs3212227 CC and rs360719 TC & $6(2.9)$ & $2(0.64)$ & $4.61(0.92-23.16)$ & 0.042 & 52.6 \\
\hline All other genotypes & $201(97.1)$ & $309(99.4)$ & 1.00 & & \\
\hline rs3212227 CC and rs360719 TC/CC & $6(2.9)$ & $2(0.64)$ & $4.61(0.92-23.16)$ & 0.042 & 52.6 \\
\hline
\end{tabular}

Significant results are indicated using bold font.

cytokines with opposing action. Thus, practical significance of the obtained results cannot yet be declared, although it does indicate a necessity and implications for further studies.

There are some limitations of our study which need to be addressed. The measurement of IL12A, Il12B, IL18 and INF-gamma serum concentrations, especially during vaccination or natural HBV transmission, was not possible due to a lack of patient material, although it could provide further information on mechanisms of anti-HBs formation in relation to the respective genotypes. An other limitation of our study is the moderate number of the examined patients, especially since genetic influences on responsiveness to HBsAg with anti-HBs development were shown in homozygotes carrying polymorphic variants of low frequency, which limits the statistical power of the study. Numerous analyses showed borderline significance and were not used to support our conclusion, as they may indicate the involvement of ILs of the Th1 pathway in the immune response to HBsAg. Therefore, large population-based studies are warranted to further elucidate the impact of the examined IL polymorphisms on anti-HBs development. Finally, we would like to stress that our results were obtained in Caucasian HD patients living in the Wielkopolska region of Poland. Prevalence of rare homozygotes of both IL12 and IL18 may vary in other ethnicities. The frequency of the IL12A rs568408 AA polymorphism in a Chinese control population was $1.2 \%$, and $18.7 \%$ for $I L 12 B$ rs3212227 CC [48], whereas in our Caucasian controls the respective frequencies were $2.5 \%$ and $5.0 \%$. Prevalence of IL18 rs360719 CC was 5.7\%, 5.5\% and 6.1\% in Spain, Italy and Argentina, respectively [17]. In controls from the South Moravia region (more proximal to Poland), the IL18 rs360719 CC frequency was 8.0\% [56]; in our study this frequency was $8.8 \%$. The ethnic differences in IL genotype prevalence may modulate the effect of ILs on the humoral and cellular immune response, but further investigations are needed for IL12 and IL18.

\section{Conclusions}

1. Polymorphisms in $I L 12 A$ and $I L 12 B$ may jointly with IL18 polymorphism contribute to anti-HBs development in HD patients.

2. In HD patients, the development of anti-HBs is associated with gene polymorphisms of ILs involved in the Th1 system.

\section{Competing interests}

The authors declare that they have no competing interests. 


\section{Authors' contributions}

AEG gave a conception, participated in the design of the study, performed a clinical interpretation of the data and wrote the manuscript. PMW performed the statistical analysis and participated in its interpretation. AM performed MDR analysis and interpreted its results. PPJ carried out the molecular genetic studies and participated in the study design. All authors read and approved the final manuscript.

\section{Acknowledgements}

We would like to express our gratitude to physicians of the dialysis centers of the Wielkopolska region of Poland for their help in collecting the participants' data and consent during the study period. We would also like to thank Dr. Margarita Lianeri for her assistance.

For the abstract of this paper we received the Best Hemodialysis Abstract Award at the $18^{\text {th }}$ International Symposium on Hemodialysis, $32^{\text {nd }}$ Annual Dialysis Conference in San Antonio, February 25, 2012.

\section{Author details}

${ }^{1}$ Chair and Department of Nephrology, Transplantology and Internal Diseases Poznań University of Medical Sciences, 49 Przybyszewskiego Blvd, 60-355 Poznań, Poland. ${ }^{2}$ Department of Biochemistry and Molecular Biology, Poznań University of Medical Sciences, Poznań, Poland.

Received: 2 November 2011 Accepted: 28 July 2012

Published: 3 August 2012

\section{References}

1. Cooksley H, Chokshi S, Maayan Y, Wedemeyer H, Andreone P, Gilson R, Warnes T, Paganin S, Zoulim F, Frederick D, Neumann AU, Brosgart CL, Naoumov NV: Hepatitis B virus e antigen loss during adefovir dipivoxil therapy is associated with enhanced virus-specific CD4+ T-cell reactivity. Antimicrob Agents Chemother 2008, 52:312-320.

2. Wu JF, Wu TC, Chen CH, Ni YH, Chen HL, Hsu HY, Chang MH: Serum levels of interleukin-10 and interleukin-12 predict early, spontaneous hepatitis B virus e antigen seroconversion. Gastroenterology 2010, 138:165-172.

3. Rossol S, Marinos G, Carucci P, Singer MV, Roger W, Naoumov NV: Interleukin-12 induction of Th1 cytokines is important for viral clearance in chronic hepatitis B. J Clin Invest 1997, 99:3025-3033.

4. Cheong JY, Cho SW, Oh B, Kimm K, Lee KM, Shin SJ, Lee JA, Park BL, Cheong HS, Shin HD, Cho BY, Kim JH: Association of interleukin-18 gene polymorphisms with hepatitis B virus clearance. Dig Dis Sci 2010, 55:1113-1119.

5. Chow YH, Chiang BL, Lee YL, Chi WK, Lin WC, Chen YT, Tao MH: Development of Th1 and Th2 populations and the nature of immune responses to hepatitis $B$ virus DNA vaccines can be modulated by codelivery of various cytokine genes. J Immunol 1998, 160:1320-1329.

6. Schirmbeck R, Reimann J: Modulation of gene-gun-mediated Th2 immunity to hepatitis B surface antigen by bacterial CpG motifs or IL-12. Intervirology 2001, 44:115-123.

7. Chen JZ, Zhu HH, Liu KZ, Chen Z: Enhancing cellular immune response to HBV M DNA vaccine in mice by codelivery of interleukin-18 recombinant. J Zhejiang Univ Sci 2004, 5:467-471.

8. Channarong S, Mitrevej A, Sinchaipanid N, Usuwantim K, Kulkeaw K, Chaicumpa W: Cloning, protein expression and immunogenicity of HBs-murine IL-18 fusion DNA vaccine. Asian Pac J Allergy Immunol 2007, 25:233-242

9. Tang LL, Liu KZ: Recent advances in DNA vaccine of hepatitis virus. Hepatobiliary Pancreat Dis Int 2002, 1:228-231.

10. Okamura H, Tsutsi H, Komatsu T, Yutsudo M, Hakura A, Tanimoto T, Torigoe K, Okura T, Nukada Y, Hattori K, et al: Cloning of a new cytokine that induces IFN-gamma production by T cells. Nature 1995, 378:88-91.

11. Yoshimoto T, Takeda K, Tanaka T, Ohkusu K, Kashiwamura S, Okamura H, Akira S, Nakanishi K: IL-12 up-regulates IL-18 receptor expression on T cells, Th1 cells, and B cells: synergism with IL-18 for IFN-gamma production. J Immunol 1998, 161:3400-3407.

12. Tominaga K, Yoshimoto T, Torigoe K, Kurimoto M, Matsui K, Hada T, Okamura H, Nakanishi K: IL-12 synergizes with IL-18 or IL-1 beta for IFNgamma production from human T cells. Int Immunol 2000, 12:151-160

13. Kim JJ, Nottingham LK, Tsai A, Lee DJ, Maguire HC, Oh J, Dentchev T, Manson KH, Wyand MS, Agadjanyan MG, Ugen KE, Weiner DB: Antigenspecific humoral and cellular immune responses can be modulated in rhesus macaques through the use of IFN-gamma, IL-12, or IL-18 gene adjuvants. J Med Primatol 1999, 28:214-223.

14. Yang W, Chaudhri G, Jackson RJ, Karupiah G: IL-12p40 and IL-18 play pivotal roles in orchestrating the cell-mediated immune response to a Poxvirus infection. J Immunol 2009, 183:3324-3331.

15. Reading PC, Whitney PG, Barr DP, Wojtasiak M, Mintern JD, Waithman J, Brooks AG: IL-18, but not IL-12, regulates NK cell activity following intranasal herpes simplex virus type 1 infection. J Immunol 2007, 179:3214-3221.

16. Harandi AM, Svennerholm B, Holmgren J, Eriksson K: Interleukin-12 (IL-12) and IL-18 are important in innate defense against genital herpes simplex virus type 2 infection in mice but are not required for the development of acquired gamma interferon-mediated protective immunity. J Virol 2001, 75:6705-6709.

17. Sánchez E, Palomino-Morales RJ, Ortego-Centeno N, Jiménez-Alonso J, González-Gay MA, López-Nevot MA, Sánchez-Román J, de Ramón E, González-Escribano MF, Pons-Estel BA, D'Alfonso S: Sebastiani GD; Italian collaborative group, Alarcón-Riquelme ME, Martín J: Identification of a new putative functional IL18 gene variant through an association study in systemic lupus erythematosus. Hum Mol Genet 2009, 18:3739-3748

18. Grzegorzewska AE, Wobszal P, Jagodziński PP: Interleukin-18 Promoter polymorphism and development of antibodies to surface antigen of hepatitis B virus in hemodialysis patients. Kidney Blood Press Res 2012, 35:1-8.

19. Recommendations for preventing transmission of infections among chronic hemodialysis patients: Morbidity and Mortality Weekly report. Centers for Disease Control and Prevention: Centers for Disease Control and Prevention: 2001:50.

20. Guidelines EBP: Prevention and management of HBV, HCV and HIV in HD patients. Nephrol Dial Transplant 2002, 17:78-87.

21. Załączniki do rozporządzenia Ministra Zdrowia z dnia 18 kwietnia: 2005

22. Hahn LW, Ritchie MD, Moore JH: Multifactor dimensionality reduction software for detecting gene-gene and gene-environment interactions. Bioinformatics 2003, 19:376-382.

23. Bruquera M, Cremades M, Mayor A, Sánchez Tapias JM, Rodés J: Immunogenicity of a recombinant hepatitis $B$ vaccine in haemodialysis patients. Postgrad Med J 1987, 63S(2):155-158.

24. Mitwalli A: Responsiveness to hepatitis $B$ vaccine in immunocompromised patients by doubling the dose scheduling. Nephron 1996, 73:417-420

25. Sorkhi H, Roushan MR: Al Hashemi GH, Dooki MR, Bai S: Response to hepatitis $B$ virus vaccination in haemodialysis patients with and without hepatitis C infection. East Mediterr Health J 2008, 14:798-803.

26. Fabrizi F, Messa PG, Lunghi G, Aucella F, Bisegna S, Mangano S, Villa M, Barbisoni F, Rusconi E, Martin P: Occult hepatitis B virus infection in dialysis patients: a multicentre survey. Aliment Pharmacol Ther 2005, 21:1341-1347

27. Sun HY, Lee HC, Liu CE, Yang CL, Su SC, Ko WC, Lin CY, Tsai JJ, Wong WW, Ho MW, Cheng SH, Lin YH, Miao WJ, Hung CC: Factors associated with isolated anti-hepatitis B core antibody in HIV-positive patients: impact of compromised immunity. J Viral Hepat 2010, 17:578-587.

28. Grzegorzewska AE, Kaczmarek-Leki V, Młot-Michalska M, Niepolski L: Seroconversion rate to positivity for antibodies against core antigen of hepatitis B virus and duration of renal replacement therapy. Nephrol Dial Transplant 2011, 26:970-976.

29. Oesterreicher C, Hammer J, Koch U, Pfeffel F, Sunder-Plassmann G, Petermann D, Müller C: HBV and HCV genome in peripheral blood mononuclear cells in patients undergoing chronic hemodialysis. Kidney Int 1995, 48:1967-1971.

30. Minuk GY, Sun DF, Greenberg R, Zhang M, Hawkins K, Uhanova J, Gutkin A, Bernstein K, Giulivi A, Osiowy C: Occult hepatitis B virus infection in a North American adult hemodialysis patient population. Hepatology 2004, 40:1072-1077.

31. Grzegorzewska AE, Kurzawska-Firlej D, Ratajewski W, Frankiewicz D, Niepolski $L$, Kaczmarek A: Antibodies to core antigen of hepatitis B virus in patients on renal replacement therapy: Association with demographic, clinical and laboratory data. Nephron Clin Pract 2010, 114:c194-c203.

32. Fabrizi F, Dixit V, Martin P, Messa P: Meta-analysis: the impact of diabetes mellitus on the immunological response to hepatitis $B$ virus vaccine in dialysis patients. Aliment Pharmacol Ther 2011, 33:815-821. 
33. Shatat $H Z$, Kotkat AM, Farghaly AG: Immune response to hepatitis $B$ vaccine in haemodialysis patients. J Egypt Public Health Assoc 2000, 75:257-275

34. Steketee RW, Ziarnik ME, Davis JP: Seroresponse to hepatitis B vaccine in patients and staff of renal dialysis centers, Wisconsin. Am J Epidemiol 1988, 127:772-782

35. Fabrizi F, Di Filippo S, Marcelli D, Guarnori I, Raffaele L, Crepaldi M, Erba G, Locatelli F: Recombinant hepatitis B vaccine use in chronic hemodialysis patients. Long-term evaluation and cost-effectiveness analysis. Nephron 1996 72:536-543.

36. He Q, Wu F, Zhang P, Chen J: Effect of high-flux hemodialysis on delayed hepatitis $B$ virus vaccination response in hemodialysis patients. Postgrad Med 2011, 123:150-152.

37. Watanabe H, Matsushita S, Kamikawaji N, Hirayama K, Okumura M, Sasazuki T: Immune suppression gene on HLA-Bw54-DR4-DRw53 haplotype controls nonresponsiveness in humans to hepatitis $B$ surface antigen via CD8+ suppressor T cells. Hum Immunol 1988, 22:9-17.

38. Hatae K, Kimura A, Okubo R, Watanabe H, Erlich HA, Ueda K, Nishimura Y, Sasazuki T: Genetic control of nonresponsiveness to hepatitis B virus vaccine by an extended HLA haplotype. Eur J Immunol 1992, 22:1899-1905.

39. Girndt M, Sester U, Sester M, Deman E, Ulrich C, Kaul H, Köhler H: The interleukin-10 promoter genotype determines clinical immune function in hemodialysis patients. Kidney Int 2001, 60:2385-2391.

40. Seder RA, Gazzinelli R, Sher A, Paul WE: IL-12 acts directly on CD41 T cells to enhance priming for IFN-g production and diminishes IL-4 inhibition in such priming. Proc Natl Acad Sci USA 1993, 90:10188-10192.

41. Wysocka M, Kubin M, Vieira LQ, Ozmen L, Garotta G, Scott P, Trinchieri G: Interleukin-12 is required for interferon-gamma production and lethality in lipopolysaccharide-induced shock in mice. Eur J Immunol 1995, 25:672-676

42. Cheema BS, Abas H, Smith BC, O'Sullivan AJ, Chan M, Patwardhan A, Kelly J, Gillin A, Pang G, Lloyd B, Berger K, Baune BT: Fiatarone Singh MA: Effect of resistance training during hemodialysis on circulating cytokines: a randomized controlled trial. Eur J Appl Physiol 2011, 111:1437-1445.

43. Ishizuka T, Nitta K, Yokoyama T, Hayashi T, Futatsuyama K, Kimata N, Miwa $\mathrm{N}$, Nishida E, Kawashima A, Akiba T, Nihei H: Increased serum levels of interleukin-12 may be associated with Th1 differentiation in hemodialysis patients. Nephron 2002, 90:503-504.

44. Klínger J, Enríquez J, Arturo JA, Delgado M, Avila G, Ceballos O: Cytokines and peritonitis in continuous ambulatory peritoneal dialysis: immunodeviation and immunodeficiency. Adv Perit Dial 2002, 18:170-176.

45. Libetta C, Rampino T: Dal Canton A: Polarization of T-helper lymphocytes toward the Th2 phenotype in uremic patients. Am J Kidney Dis 2001 38:286-295.

46. Sester U, Sester M, Hauk M, Kaul H, Köhler H, Girndt M: T-cell activation follows Th1 rather than Th2 pattern in haemodialysis patients. Nephrol Dial Transplant 2000, 15:1217-1223.

47. Lonnemann G, Novick D, Rubinstein M, Dinarello CA: Interleukin-18, interleukin-18 binding protein and impaired production of interferon-gamma in chronic renal failure. Clin Nephrol 2003, 60:327-334.

48. Liu L, Xu Y, Liu Z, Chen J, Zhang Y, Zhu J, Liu J, Liu S, Ji G, Shi H, Shen H, Hu Z: IL12 polymorphisms, HBV infection and risk of hepatocellular carcinoma in a high-risk Chinese population. Int J Cancer 2011, 128:1692-1696.

49. Morahan G, Huang D, Ymer SI, Cancilla MR, Stephen K, Dabadghao P, Werther G, Tait BD, Harrison LC, Colman PG: Linkage disequilibrium of a type 1 diabetes susceptibility locus with a regulatory IL12B allele. Nat Genet 2001, 27:218-221.

50. Davoodi-Semiromi A, Yang JJ, She JX: IL-12p40 is associated with type 1 diabetes in Caucasian-American families. Diabetes 2002, 51:2334-2336.

51. Seegers D, Zwiers A, Strober W, Peña AS, Bouma G: Taq I polymorphism in the 3_-UTR of the IL-12 p40 gene correlates with increased IL-12 secretion. Genes Immun 2002, 3:419-423.

52. Yilmaz V, Yentür SP, Saruhan-Direskeneli G: IL-12 and IL-10 polymorphisms and their effects on cytokine production. Cytokine 2005, 30:188-194.

53. Hennig BJ, Fielding K, Broxholme J, Diatta M, Mendy M, Moore C, Pollard AJ, Rayco-Solon P, Sirugo G, van der Sande MA, Waight P, Whittle HC, Zaman $S M$, Hill AV, Hall AJ: Host genetic factors and vaccine-induced immunity to hepatitis B virus infection. PLoS One 2008, 3:e1898.
54. Du DW, Jia ZS, Li GY, Zhou YY: HBV DNA vaccine with adjuvant cytokines induced specific immune responses against HBV infection. World J Gastroenterol 2003, 9:108-111.

55. Livingston BD, Alexander J, Crimi C, Oseroff C, Celis E, Daly K, Guidotti LG, Chisari FV, Fikes J, Chesnut RW, Sette A: Altered helper T lymphocyte function associated with chronic hepatitis B virus infection and its role in response to therapeutic vaccination in humans. J Immunol 1999, 162:3088-3095.

56. Izakovicova Holla L, Hrdlicková B, Schüller M, Buckova D, Kindlova D, Izakovic V, Vasku A: Haplotype analysis of the interleukin-18 gene in Czech patients with allergic disorders. Hum Immunol 2010, 71:592-597.

doi:10.1186/1471-2369-13-75

Cite this article as: Grzegorzewska et al:: Antibodies to hepatitis B virus surface antigen and interleukin 12 and interleukin 18 gene polymorphisms in hemodialysis patients. BMC Nephrology 2012 13:75.

\section{Submit your next manuscript to BioMed Central and take full advantage of:}

- Convenient online submission

- Thorough peer review

- No space constraints or color figure charges

- Immediate publication on acceptance

- Inclusion in PubMed, CAS, Scopus and Google Scholar

- Research which is freely available for redistribution 